\title{
The 19th IEEE Conference on Nanotechnology (IEEE-NANO 2019)
}

正員 川合 健太郎 (大阪大学)

\section{1. 開 催 地}

IEEE-NANO 2019 は 2019 年 7 月 22〜26 日の日程で, 中国・マカオ (澳門) 特別行政区の Parisian Macao で開催 された。General Chair は中国科学院の Lianqing Liu 教授, General Co-Chair は香港城市大学の Wen Jung Li 教授, Program Chair はピッツバーグ大学の Guangyong Li 教授 が務めた。

マカオは香港と同じく珠江の河口部に位置している。 1997 年のイギリスからの香港返還に続き, 1999 年にポル トガルから返還され，現在は特別行政区である。香港ドル 同様にマカオパタカと呼ばれる独自通貨が利用されている。 香港の後背地の深圳市と同様にマカオの後背地の珠海市は 経済特区に指定され，この珠江デルタ一帯は経済発展が著 しい。

ポルトガル統治時代の街並みも保存され，マカオ歴史地 区はユネスコ世界遺産として登録されている。カジノでも 有名であり, ホテル・ショッピングモール・カジノを一体化 した大規模な観光施設が数多く存在する。会場の Parisian Macao はショッピングモールを併設したホテルで，その名 の通りフロントには $1 / 2$ サイズのエッフェル塔レプリカが 配置され，内装もパリを意識した作りであった（図 1)。

\section{2. 会議概要}

プレナリー講演が 6 件, キーノート講演が 6 件のほか, 通常セッション, 招待セッション, アワードセッションで 計 191 件のオーラル発表と 36 件のポスター発表が行われ た。これらのセッションには 28 の国・地域から計 308 件の 投稿があり， 233 件が採択され，採択率は $75 \%$ であった。 国・地域別投稿数では中国からの 171 件が最多で, 次にア メリカからの 38 件, インドからの 20 件が続く。韓国, 台 湾, 日本, シンガポールがそれぞれ 17 件, 13 件, 10 件, 6 件であり, 開催地の関係からか東アジアからの投稿割合が 高かった。

プレナリー講演では香港城市大学 Alex K.-Y. Jen 教授から ペロブスカイト系太陽電池の作製と高効率化に関する講演 が，NASA 主任研究員の Meyya Meyyappan からはムーア の法則の限界を迎えつつある半導体デバイスの今後のトレ ンドや新技術に関する講演が，ジョージア工科大学 Zhong lin Wang 教授からは静電気発電の発電原理と様々なアプリ ケーションに関する講演が，カリフォルニア大学 Paul S.
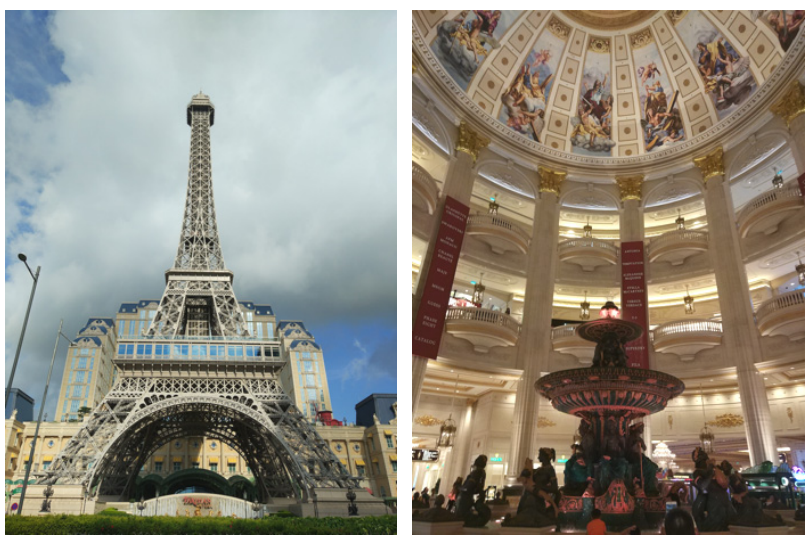

図 1 会場外観とエントランスホール

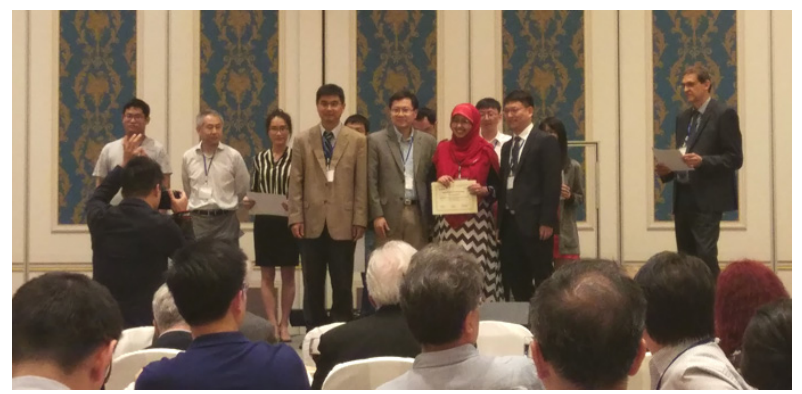

図 2 表彰式の様子

Weiss 教授からはナノスケールの各種物性に関する講演が， ミネソタ大学 Tianhong Cui 教授からは重合体収縮を用いた ナノリソグラフィやハイアスペクト比構造を用いたアプリ ケーションに関する講演が，ライス大学 Pulickel M. Ajayan 教授からは二次元結晶の物性科学に関する講演が, 京都大 学田畑教授からはDNAナノ構造体作製技術と MEMS のの 展開に関する講演が行われた。

一般口頭セッションはナノエレクトロニクス, ナノマテ リアル，2D マテリアル，ナノファブリケーション，ナノバ イオシステム，ナノバイオイメージング，ナノロボティク ス，フレキシブルエレクトロニクス，エナジーハーベスティ ングなど, 分子レベルの物性や運動, ナノサイズの材料や 機能に関するセッションで構成され，5 パラレルセッション の各会場で活発な議論が行われた。

次回の IEEE-NANO 2020 はカナダ・モントリオールに て 7 月 28〜31 日の日程で開催される。ナノに関連した分野 にご興味のある諸氏は参加を検討されたい。

(令和元年 9 月 9 日受付) 